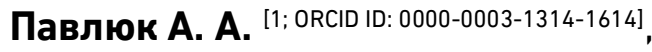

асистент

${ }^{1}$ Національний університетводного господарства та природокористування, м. Рівне

\title{
АНАЛІЗ ПРОЦЕСІВ ТРАНСНАЦІОНАЛІЗАЦІЇ КОМПАНІЙ КРАЇН СХІДНОї АЗІї
}

Мета статті полягає у виявлені основних факторів транснаціоналізації компаній країн Східної Азії (Японії, Китаю та Республіка Корея). Проаналізовано процеси транснаціоналізації у країнах Східної Азії, виявлені основні найбільші транснаціональні корпорації Японії, Китаю та Республіки Корея. Встановлено основні фактори транснаціоналізації компаній країн регіону, а саме: кон'юнктура світових ринків, витрати виробництва, умови ведення бізнесу та політика держави у сфері інвестування.

Ключові слова: фактори транснаціоналізації компаній; інвестування; показник транснацоналізації бізнесу; транснаціональні корпорації; країни Східної Азії.

Вступ. Процес транснаціоналізації виробництва виник як необхідність сучасного світового господарства. Економічні процеси транснаціоналізації обумовлені найбільшою можливістю та необхідністю переміщення капіталу 3 країн 3 його відносним надлишком у країни з його дефіцитом, де $є$ у надлишку інші фактори виробництва, які не можуть бути ефективно використані у відтворювальних процесах через нестачу капіталу [1].

Мультинаціональні та транснаціональні компанії виступають одними з основних драйверів розвитку транснаціоналізації східноазійського регіону. У даному регіоні склалася ситуація, яка стимулює транснаціоналізацію, а саме - вільна ліквідність у національних компаній, які намагаються більш ефективно використовувати наявний у них капітал.

Аналіз останніх досліджень. Діяльність транснаціональних корпорацій досліджувалися такими вітчизняними та іноземними науковцями : Гриффин Р., Пастей М., Якубовський С. А., Голіков А. П., Довгаль О. А., Кулішов В. В. та інші.

Незважаючи на існуючий інтерес до дослідження процесів транснаціоналізації компаній країн Східної Азії, є окремі аспекти, які ще досі лишаються не дослідженими. 
Метою статті є виявити основні фактори транснаціоналізації компаній країн Східної Азії, а саме - кон'юнктура світових ринків, витрати виробництва, умови ведення бізнесу та політика держави у сфері інвестування.

За даними дослідження UNCTAD, на сьогодні у світі нараховується близько 140 тис. транснаціональних корпорацій (табл. 1), і їхня кількість з кожним роком збільшується.

Зростання кількості транснаціональних компаній у світі значно впливає на розвиток економік країн Східної Азії. У міжнародний рейтинг 500 найбільших корпорацій світу, дохід яких становить 31,2 трлн дол., а прибуток у 2015 р. склав 1,7 трлн дол., та компаній, які створили понад 65 млн робочих місць у 36 країнах світу, входять компанії з головними офісами в країнах Східної Азії [2; 3]. Більш детально розглянемо провідні країни цього регіону.

Японія представлена у даному рейтингу 50 компаніями, найбільша з яких - компанія Toyota Motor - займає 9 сходинку рейтингу з оборотом 247,702 млрд дол., доходом 19,76 млрд дол., загальними активами у 398,05 млрд дол. [2; 3].

Японські корпорації активно інвестують як за кордон, так і всередині країни. Однак корпоративне інвестування має певні обмеження всередині країни, що пов'язано із соціальноекономічними факторами, такими як, наприклад, старіння нації (у 2019 р. кожен 4-й японець був старше 65 років). Також досить високі фонди оплати праці японських працівників зменшують норми прибутку для корпорацій. Таким чином, японські фірми починають експансію як на ринки Східної Азії (зокрема Китай), так і на інші азійські та європейські ринки [4]. Можна виділити основні фактори транснаціоналізації японських компаній (табл. 1).

Наведені в табл. 2 фактори стимулюють японський бізнес активно інвестувати та здійснювати діяльність за межами країни. За даними рейтингу Forbes 2000, у 2015 р. до 100 найбільших публічних компаній світу входять 7 японських компаній, а саме:

Toyota Motor займає 11 місце в рейтингу, з обсягом продажів на рівні 252,2 млрд дол., прибутком в 19,1 млрд дол. загальними активами у 389,7 млрд дол. і ринковою вартістю 239 млрд дол.;

Mitsubishi UFJ Financial - 33 місце в рейтингу, обсяги продажів - 49,2 млрд дол., прибуток - 10,6 млрд дол., загальні активи 2328,5 млрд дол., ринкова вартість компанії становить 90,9 млрд дол.;

Nippon Telegraph \& Tel - 58 місце в рейтингу, ринкова вартість компанії становить 90,9 млрд дол. 


\section{Таблиця 1}

Фактори транснаціоналізації японських компаній

\begin{tabular}{|c|c|c|c|}
\hline \multirow{2}{*}{$\begin{array}{c}\text { Зовнішні } \\
\text { умови }\end{array}$} & \multirow{2}{*}{$\begin{array}{c}\text { Стимулюючі фактори } \\
\text { для виходу на зовнішні } \\
\text { ринки }\end{array}$} & \multicolumn{2}{|c|}{$\begin{array}{c}\text { Фактори, що сприяють японським } \\
\text { інвестиціям }\end{array}$} \\
\hline & & Розвинені країни & $\begin{array}{c}\text { Азійські країни, що } \\
\text { розвиваються }\end{array}$ \\
\hline $\begin{array}{c}\text { Кон'юнктура } \\
\text { світових } \\
\text { товарних і } \\
\text { фінансових } \\
\text { ринків }\end{array}$ & $\begin{array}{l}\text { - Перенасичення } \\
\text { внутрішнього ринку; } \\
\text { - макроекономічні } \\
\text { фактори розвитку } \\
\text { економіки } \text { Японії } \\
\text { (ревальвація єни); } \\
\text { - нагромадження } \\
\text { значних фінансових } \\
\text { ресурсів }\end{array}$ & $\begin{array}{l}\text { - Високий попит } \\
\text { на японську } \\
\text { продукцію; } \\
\text { - високий } \\
\text { потенціал } \\
\text { ринку; } \\
\text { - значна та } \\
\text { глибина шитата ринків } \\
\text { широта }\end{array}$ & $\begin{array}{l}\text { - Значний потенціал } \\
\text { зростання ринків; } \\
\text { - значний } \\
\text { потенційний обсяг } \\
\text { ринків збуту; } \\
\text { - активний } \\
\text { інтеграційний } \\
\text { процес країн, що } \\
\text { розвиваються; } \\
\text { - доступ до ринків } \\
\text { ресурсів; } \\
\text { - високі темни } \\
\text { економічного } \\
\text { зростання }\end{array}$ \\
\hline $\begin{array}{c}\text { Витрати } \\
\text { виробництва }\end{array}$ & $\begin{array}{lr}\text { - Висока вартість } \\
\text { робочої сили; } \\
\text { - дефіцит людських } \\
\text { ресурсів } \\
\text { старіння нації; } \\
\text { - дефіцит природних } \\
\text { ресурсів }\end{array}$ & \begin{tabular}{|l|} 
- Добре \\
розвинута \\
інфраструктура; \\
- скорочення \\
трансакційних \\
та логістичних \\
витрат \\
\end{tabular} & $\begin{array}{l}\text { - Відносно дешева } \\
\text { робоча сила; } \\
\text { - високий природно- } \\
\text { ресурсний потенціал; } \\
\text { - інфраструктура, що } \\
\text { активно } \\
\text { розвивається }\end{array}$ \\
\hline $\begin{array}{c}\text { Умови } \\
\text { ведення } \\
\text { бізнесу та } \\
\text { державна } \\
\text { політика }\end{array}$ & $\begin{array}{l}\text { - Висока внутрішня } \\
\text { конкуренція; } \\
\text { - зростання } \\
\text { конкуренції } \\
\text { на зовнішніх ринках } \\
\text { через зниження } \\
\text { глобального попиту; } \\
\text { - державна політика } \\
\text { стимулювання } \\
\text { здійснення зовнішніх } \\
\text { інвестицій та ведення } \\
\text { бізнесу за кордоном }\end{array}$ & $\begin{array}{l}\text { - Отримання } \\
\text { іміджевих } \\
\text { бенефіцій; } \\
\text { - відсутність } \\
\text { торгівельних і } \\
\text { валютних } \\
\text { бар'єрів; } \\
\text { - стійка правова } \\
\text { система щодо } \\
\text { захисту } \\
\text { інвестицій }\end{array}$ & $\begin{array}{l}\text { - Відсутність } \\
\text { соціокультурних } \\
\text { бар'єрів; } \\
\text { - довготривалі } \\
\text { економічні зв'язки з } \\
\text { країнами регіону; } \\
\text { - можливість } \\
\text { налагодити } \\
\text { кооперацію } \\
\text { місцевими ви } \\
\text { підприємствами; } \\
\text { - досить низька } \\
\text { конкуренція; } \\
\text { - наявність інформації } \\
\text { щодо ведення } \\
\text { бізнесу в країні; } \\
\text { - спрямованість } \\
\text { державної політики } \\
\text { на залучення } \\
\text { інвестицій }\end{array}$ \\
\hline
\end{tabular}

Джерело: складено автором за [2] 
Таким чином, загальний індекс транснаціоналізації інвестиційної діяльності міжнародного бізнесу країни буде розраховуватись за обсягом:

обсяг продажів - 104,7 млрд дол., прибуток - на рівні 71,5 млрд дол.;

+ Softbank - займає 62 місце в рейтингу, сукупний оборот компанії складає 80,6 млрд дол., прибуток - 5,8 млрд дол., вартість активів - 168,8 млрд дол., ринкова вартість компанії - 70,3 млрд дол.;

+ Honda Motor - 63 місце в рейтингу, щорічний оборот компанії складає приблизно 117,1 млрд дол., дохід - 5,6 млрд дол. загальні активи - 148,7 млрд дол., ринкова вартість компанії - 61,4 млрд дол.;

+ Sumitomo Mitsui Financial - 77 місце в рейтингу, щорічний оборот на рівні 34,8 млрд дол., прибуток - 7,7 млрд дол., загальні активи складають 1465,4 млрд дол., ринкова вартість компанії 54,8 млрд дол.;

+ Nissan Motor - 96 місце в рейтингу, оборот компанії становить 100,7 млрд дол., прибуток - 4,3 млрд дол., загальні активи - 138,9 млрд дол., ринкова вартість - 45,9 млрд дол. [5].

У рейтингу ЮНКТАД, що включає в себе 100 найбільших нефінансових корпорацій, Китай (разом з Гонконгом і Тайванем) представлений лише п'ятьма корпораціями. Можна виділити основні фактори транснаціоналізації китайських компаній (табл. 2).

Таблиця 2

Фактори транснаціоналізацї китайських компаній

\begin{tabular}{|c|c|c|c|}
\hline \multirow{2}{*}{ Зовнішні умови } & \multirow{2}{*}{$\begin{array}{c}\text { Стимулюючі фактори } \\
\text { для виходу на } \\
\text { зовнішні ринки }\end{array}$} & \multicolumn{2}{|c|}{$\begin{array}{c}\text { Фактори, що сприяють китайським } \\
\text { інвестиціям }\end{array}$} \\
\hline & & Розвинені країни & $\begin{array}{c}\text { Азійські країни, що } \\
\text { розвиваються }\end{array}$ \\
\hline $\begin{array}{c}\text { Кон'юнктура } \\
\text { світових } \\
\text { товарних і } \\
\text { фінансових } \\
\text { ринків }\end{array}$ & $\begin{array}{l}\text { - Недостатній розвиток } \\
\text { внутрішнього попиту; } \\
\text { - наявність значних } \\
\text { акумульованих } \\
\text { фінансових ресурсів; } \\
\text { - наявність передових } \\
\text { технологій; } \\
\text { - матеріально-технічна } \\
\text { база }\end{array}$ & $\begin{array}{l}\text { - Стабільний попит } \\
\text { на продукцію; } \\
\text { - значний } \\
\text { потенціал ринку; } \\
\text { - значна глибина } \\
\text { та широта ринків }\end{array}$ & $\begin{array}{l}\text { - Значний } \\
\text { потенціал } \\
\text { зростання ринків; } \\
\text { - значний } \\
\text { потенційний обсяг } \\
\text { ринків збуту; } \\
\text { - активний } \\
\text { інтеграційний } \\
\text { процес країн, що } \\
\text { розвиваються; } \\
\text { - високі темпи } \\
\text { економічного } \\
\text { зростання }\end{array}$ \\
\hline
\end{tabular}


продовження табл. 2

\begin{tabular}{|c|c|c|c|}
\hline $\begin{array}{c}\text { Витрати } \\
\text { виробництва }\end{array}$ & $\begin{array}{l}\text { Невисокі витрати на } \\
\text { робочу силу; } \\
\text { низька кваліфікація } \\
\text { робочої сили }\end{array}$ & $\begin{array}{l}\text { - Добре розвинута } \\
\text { інфраструктура; } \\
\text { - скорочення } \\
\text { трансакційних і } \\
\text { - логістичних витрат }\end{array}$ & $\begin{array}{l}\text { - Інфраструктура, } \\
\text { що активно } \\
\text { розвивається }\end{array}$ \\
\hline $\begin{array}{c}\text { Умови } \\
\text { ведення } \\
\text { бізнесу та } \\
\text { державна } \\
\text { політика }\end{array}$ & $\begin{array}{l}\text { - Державне управління } \\
\text { великими інвестиціями } \\
\text { за кордоном; } \\
\text { - Становлення } \\
\text { китайських брендів; } \\
\text { - необхідність } \\
\text { отримання додаткових } \\
\text { прибутків та ресурсів }\end{array}$ & $\begin{array}{l}\text { - Отримання } \\
\text { іміджевих } \\
\text { бенефіцій; } \\
\text { - стійка правова } \\
\text { система щодо } \\
\text { захисту інвестицій }\end{array}$ & $\begin{array}{l}\text { - Довготривалі } \\
\text { економічні зв'язки } \\
\text { з країнами регіону; } \\
\text { - досить низька } \\
\text { конкуренція; } \\
\text { - наявність } \\
\text { інформації щодо } \\
\text { ведення бізнесу в } \\
\text { країні; } \\
\text { - спрямованість } \\
\text { державної політики } \\
\text { на залучення } \\
\text { інвестицій }\end{array}$ \\
\hline
\end{tabular}

Джерело: складено автором за [2]

Китай досить жорстко регулює діяльність підприємств щодо здійснення міжнародних інвестицій. Основними державними органами КНР, що регулюють діяльність іноземних інвесторів на території Китаю, а також діяльність китайських інвесторів у зарубіжних проєктах, є Державний комітет КНР з розвитку і реформи (Департамент іноземних інвестицій ДКРР), Міністерство комерції КНР (Департамент економічного співробітництва із зарубіжними країнами Мінкомерції). Як вже зазначалось раніше, до рейтингу ЮНКТАД включено п'ять китайських невиробничих компаній.

В Китаї, тільки 20\% активів приходяться на закордонні філії. Це пояснюється тим, що китайські компанії зосереджують своє виробництво на території країни - через наявність досить дешевих трудових ресурсів та матеріально-технічної бази, водночас зарубіжні активи в більшості випадків складаються 3 торгових представництв, відділів розробки та проєктування.

Як вже зазначалося вище, Китай не створив поки що власних міжнародних брендів, які могли б конкурувати з європейськими чи американськими компаніями. Це пояснює доволі низьку (у середньому 30\%) частку виручки великими компаніями від торгівлі на міжнародних ринках.

Щодо корейських корпорацій, то вони не представлені в рейтингу Fortune 500. Однак, за даними рейтингу Forbes 2000 за 2015 р., корейські компанії досить впевнено входять, починаючи 3 
другої сотні, до списків рейтингу (табл. 3).

Таблиця 3

Рейтинг корейських корпорацій у Forbes 2000

\begin{tabular}{|c|c|c|c|c|c|}
\hline $\begin{array}{c}\text { Місце в } \\
\text { рейтингу }\end{array}$ & $\begin{array}{c}\text { Міжнародна назва } \\
\text { компанії }\end{array}$ & $\begin{array}{c}\text { Обсяги } \\
\text { продажів, } \\
\text { млрд дол. }\end{array}$ & $\begin{array}{c}\text { Прибуток, } \\
\text { млрд дол. }\end{array}$ & $\begin{array}{c}\text { Активи, } \\
\text { млрд дол. }\end{array}$ & $\begin{array}{c}\text { Ринкова } \\
\text { вартість, } \\
\text { млрд дол. }\end{array}$ \\
\hline 18 & $\begin{array}{c}\text { Samsung } \\
\text { Electronics }\end{array}$ & 195,9 & 21,9 & 209,6 & 199,4 \\
\hline 117 & Hyundai Motor & 84,8 & 7 & 133,9 & 32,9 \\
\hline 71 & $\begin{array}{c}\text { Korea Electric } \\
\text { Power }\end{array}$ & 54,6 & 2,6 & 148,9 & 27 \\
\hline 279 & $\begin{array}{c}\text { Shinhan Financial } \\
\text { Group }\end{array}$ & 20,1 & 1,9 & 307,5 & 17,8 \\
\hline 300 & Hyundai Mobis & 34,4 & 3,3 & 35,6 & 21,1 \\
\hline 310 & Samsung Life & 24,3 & 1,3 & 195 & 17,9 \\
\hline KInsurance & KIA Motors & 44,7 & 2,8 & 37,3 & 16,4 \\
\hline
\end{tabular}

Джерело: складено автором за [5]

Корейські компанії, зокрема Samsung Electronics, активно здійснює інвестування в іноземні компанії. Так, обсяг іноземних активів у 2019 р. для даної компанії склав 46,42 млрд дол., що становить 22\% від загальних активів. Незважаючи на досить незначний показник інтернаціоналізації інвестування, інтернаціоналізація продажів для корейських компаній становить близько 90\%, що також пояснює значну кількість іноземного персоналу, що становить 60 \% від всього персоналу компанії [5].

Корея - країна-експортер капіталу, про що свідчать офіційні статистичні дані. Виходячи 3 вищезазначених факторів транснаціоналізації корейських компаній, можна сказати, що в більшості випадків вони схожі з аналогічними факторами Японії та Китаю.

Висновки. Таким чином, за результатами проведеного аналізу можна зробити такі висновки. Існують основні фактори, що забезпечують інтернаціоналізацію бізнесу корпорацій провідних країн регіону Східної Азії. Серед них можна виділити фактори, пов'язані з демографією та економікою. Сприятливі умови ведення бізнесу в інших країнах, передусім в країнах, що розвиваються, та інших розвинених країнах Східної Азії, та загалом Південно-Східного регіону, сприяють міжнародному бізнесу компаній країн Східної Азії, але також вони зосереджують половину своїх активів саме у своїх країнах, тим самим підтримуючи рівень економічного зростання 
національних економік, рівень зайнятості та обсяг споживання.

1. Глобалізація та регіоналізація як вектори розвитку міжнародних економічних відносин : колективна монографія / А. П. Голіков, О.А.Довгаль, Н.А.Казакова та ін. ; за ред. О. А. Довгаль, Н. А. Казакової. Харків : ХНУ імені В. Н. Каразіна, 2018. 540 с. URL: http://dspace.univer.kharkov.ua/handle/123456789/14766 (дата звернення: 22.05.2020). 2. Platforma Czasopizm URL: https://www.studocu.com/en$\mathrm{nz} /$ document/victoria-university-of-wellington/geographies-of-

globalisation/essays/transnational-corporations-are-the-most-important-actors-intodays-global-economy-describe-the-rise-of-tncs-and-assess-to-what-extent-thisstatement-is-true/8383028/view (дата звернення: 22.05.2020). 3. Доклад о мирових инвестициях 2015 год. Конференция ЮНКТАД. URL: https://unctad.org/en/PublicationsLibrary/wir2019_en.pdf (дата звернення: 22.05.2020). 4. Кулішов В. В. Транснаціональна експансія світової економіки. Бізнес Інформ. 2015. № 4. С. 58-61. 5. The World's Largest Companies. URL: http://www.forbes.com/global2000/ranking-2019/list/\#tab:overall (дата звернення: 22.05.2020). 6. United Nations Conference on Trade and Development. URL: https://unctad.org/en/pages/PublicationWebflyer.aspx?publicationid=2466 (дата звернення: 22.05.2020). 7. Гриффин Р., Пастей М. Международный бизнес. / пер. с англ. под ред. А. Г. Медведева. 4-е изд. СПб.: ИД «Питер», 2006. 1088 с. 8. Министерство Коммерции Китайской Народной Республики. URL: http://russian.mofcom.gov.cn/column/statistic.shtml (дата звернення: 22.05.2020).

\section{REFERENCES:}

1. Hlobalizatsiia ta rehionalizatsiia yak vektory rozvytku mizhnarodnykh ekonomichnykh vidnosyn : kolektyvna monohrafiia / A. P. Holikov, O. A. Dovhal, N. A. Kazakova ta in. ; za red. 0. A. Dovhal, N. A. Kazakovoi. Kharkiv : KhNU imeni V. N. Karazina, $2018 . \quad 540 \quad$ s. $\quad$ URL: http://dspace.univer.kharkov.ua/handle/123456789/14766 (data zvernennia: 22.05.2020). 2. Platforma Czasopizm URL: https://www.studocu.com/en$\mathrm{nz} /$ document/victoria-university-of-wellington/geographies-of-

globalisation/essays/transnational-corporations-are-the-most-important-actors-intodays-global-economy-describe-the-rise-of-tncs-and-assess-to-what-extent-thisstatement-is-true/8383028/view (data zvernennia: 22.05.2020). 3. Doklad o myrovykh ynvestytsyiakh 2015 hod. Konferentsyia YUNKTAD. URL: https://unctad.org/en/PublicationsLibrary/wir2019_en.pdf (data zvernennia: 22.05.2020). 4. Kulishov V. V. Transnatsionalna ekspansiia svitovoi ekonomiky. Biznes Inform. 2015. № 4. S. 58-61. 5. The Worlds Largest Companies. URL: http://www.forbes.com/global2000/ranking-2019/list/\#tab:overall (data zvernennia: 22.05.2020). 6. United Nations Conference on Trade and Development. URL: https://unctad.org/en/pages/PublicationWebflyer. aspx?publicationid=2466 (data zvernennia: 22.05.2020). 7. Griffin R., Pastey M. Mejdunarodnyiy biznes. / per. s angl. pod red. A. G. Medvedeva. 4-e izd. SPb. : ID «Piter», 2006. 1088 s. 8. Ministerstvo Kommertsii Kitayskoy Narodnoy Respubliki. URL: http://russian.mofcom.gov.cn/column/statistic.shtml (data zvernennia: 22.05.2020). 


\section{ANALYSIS OF TRANSNATIONALIZATION PROCESSES OF COMPANIES IN EASTERN ASIA}

The article examines the scientific foundations and okharakterizovan the formation and development processes of transnationalization of companies in Eastern Asia.

The relevance of this article due to the fact that in the conditions of globalization is dramatically accelerating the process of liberalization of national economies and world markets, trade, information and there is a «new» economy, which inevitably leads to the emergence of new and transformation of previously existing business entities, the main activity of which it becomes a transnational business.

The goal of the article lies in detection of the main factors of the transnationalization of companies of the East Asian countries (Japan, China and Republic of Korea). Analyzes processes of transnationalization in the economies of East Asia, identifies the main biggest transnational corporations of Japan, China and the Republic of Korea. The main factors of the transnationalization of companies of the countries of the region, namely the situation on the world markets, production costs, the business environment and state policy in the sphere of investments.

According to the results of the research are formulated the conclusion that the system of transnational business in Japan and the Republic of Korea are similar and based on identical or similar in meaning features. The system of transnational business of China is different. And formed generalizations that should be taken into consideration to assess the level of transnationalisation of business activities in the countries of East Asia and the main calculation of the indicators of transnationalization of investment, trade and employment, and the index value international companies, which allows us to assess the impact of existing international business, evaluate the processes of transnationalization of the country in terms of transformation of the global economic environment.

Keywords: factors of transnationalization of companies; investment; indicator of transnationalization of business; transnational corporations; countries of Eastern Asia. 
Павлюк А. А. ${ }^{[1 ; 0 R C I D ~ I D: ~ 0000-0003-1314-1614], ~}$

ассистент

${ }^{1}$ Национальный университет водного хозяйства и природопользования, г. Ровно

\section{АНАЛИЗ ПРОЦЕССОВ ТРАНСНАЦИОНАЛИЗАЦИИ КОМПАНИЙ СТРАН ВОСТОЧНОЙ АЗИИ}

Цель статьи заключается в определении основных факторов транснационализации компаний стран Восточной Азии (Японии, Китая и Республики Корея). Проанализированы процессы транснационализации В странах Восточной Азии, определены основные крупные транснациональные корпорации Японии, Китая и Республики Корея. Выявлены основные факторы транснационализации компаний стран региона, а именно: конъюнктура мировых рынков, затраты производства, условия ведения бизнеса и политика государства В сфере инвестирования.

Ключевые слова: факторы транснационализации компаний;

инвестирование; показатель транснацонализации бизнеса; транснациональные корпорации; страны Восточной Азии. 